\title{
Haloferax prahovense sp. nov., an extremely halophilic archaeon isolated from a Romanian salt lake
}

Correspondence

Madalin Enache

madalin.enache@ibiol.ro

\author{
Madalin Enache, ${ }^{1,2}$ Takashi Itoh, ${ }^{1}$ Masahiro Kamekura, ${ }^{3}$ Gabriela Teodosiu ${ }^{2}$ \\ and Lucia Dumitru ${ }^{2}$
'Japan Collection of Micro-organisms RIKEN BioResource Center, Wako-shi, Saitama-ken 351-0198, Japan Bucharest 060031, Romania \\ ${ }^{2}$ Institute of Biology of the Romanian Academy, Splaiul Independentei 296, PO Box 56-53, \\ ${ }^{3}$ Halophiles Research Institute, 677-1 Shimizu, Noda-shi, Chiba-ken 278-0043, Japan
}

Extremely halophilic archaea are micro-organisms that require high salt concentrations for growth and inhabit hypersaline environments such as the Dead Sea and the Great Salt Lake. They are classified in the family Halobacteriaceae and the various species constitute 22 recognized genera (Wainø et al., 2000; Grant et al., 2001; Hezayen et al., 2002; Oren et al., 2002; Vreeland et al., 2002; Itoh et al., 2005; Xue et al., 2005; Castillo et al., 2006a, b). Hypersaline environments, such as salt mines and salt lakes, are commonly found in Romania. Samples taken from five salt lakes (Telega, Bride Cave, Red Bath, Green Bath and Shepherd Bath) located in Prahova county (near Slanic Prahova city) and from one (Techirghiol Lake) close to the Black Sea coast, have led to the isolation of a number of halobacteria in media with a high $\mathrm{Mg}^{2+}$ concentration and taxonomic investigations have been partially conducted for 19 strains (Enache et al., 2000). Analysis of the partial 16S rRNA gene sequences of these strains suggested that many of them belonged to the genus Haloferax. The genus Haloferax includes species in which growth occurs in media containing 1.5-4.5 $\mathrm{M} \mathrm{NaCl}$ and high $\mathrm{Mg}^{2+}$ concentrations and species

The GenBank/EMBL/DDBJ accession number for the 16S rRNA gene sequence of strain TL6 $^{\top}$ is $A B 258305$. display a characteristic polar lipid composition (Ventosa, 2001; Kamekura et al., 2004). The species currently recognized within this genus are Haloferax volcanii (Mullakhanbhai \& Larsen, 1975; Torreblanca et al., 1986), Haloferax denitrificans (Tomlinson et al., 1986; Tindall et al., 1989), Haloferax gibbonsii (Juez et al., 1986), Haloferax mediterranei (Rodriguez-Valera et al., 1983), Haloferax alexandrinus (Asker \& Ohta, 2002), Haloferax lucentense (Gutierrez et al., 2002) and Haloferax sulfurifontis (Elshahed et al., 2004).

In this paper, we describe the detailed characterization of one representative strain from our salt lake isolates and a novel species is proposed.

Strain $\mathrm{TL}^{\mathrm{T}}$ was isolated from a surface water sample from Telega Lake, a saline continental lake in Prahova County, around $100 \mathrm{~km}$ north of Bucharest, Romania, with a salinity of around $161 \mathrm{~g} \mathrm{l}^{-1}$. The water sample was collected in an autoclaved glass bottle and kept in a refrigerator until plating. The novel strain was isolated in a medium with the following composition $\left(\mathrm{l}^{-1}\right): 125 \mathrm{~g} \mathrm{NaCl}, 160 \mathrm{~g}$ $\mathrm{MgCl}_{2} \cdot 6 \mathrm{H}_{2} \mathrm{O}, 5 \mathrm{~g} \mathrm{~K}_{2} \mathrm{SO}_{4}, 0.1 \mathrm{~g} \mathrm{CaCl} \cdot 2 \mathrm{H}_{2} \mathrm{O}, 1 \mathrm{~g}$ yeast extract, $1 \mathrm{~g}$ peptone (Difco), $2 \mathrm{~g}$ soluble starch and $20 \mathrm{~g}$ agar. The $\mathrm{pH}$ of the medium was 7.0-7.2 before sterilization. 
For further experiments, the novel strain was either grown in this medium or in JCM 168 medium which contained $\left(1^{-1}\right)$ : $5 \mathrm{~g}$ Casamino acids, 5 g yeast extract, $1 \mathrm{~g}$ sodium glutamate, $3 \mathrm{~g}$ trisodium citrate, $29.5 \mathrm{~g} \mathrm{MgSO}_{4} .7 \mathrm{H}_{2} \mathrm{O}, 2 \mathrm{~g} \mathrm{KCl}, 175.5 \mathrm{~g}$ $\mathrm{NaCl}, 0.036 \mathrm{~g} \mathrm{FeCl}_{2} \cdot 4 \mathrm{H}_{2} \mathrm{O}$ and $0.36 \mathrm{mg} \mathrm{MnCl}_{2} \cdot 4 \mathrm{H}_{2} \mathrm{O}$. Before sterilization, the $\mathrm{pH}$ of the medium was 7.0-7.2. Cultures were incubated at $38^{\circ} \mathrm{C}$ with shaking at 180 r.p.m. Haloferax gibbonsii JCM $8863^{\mathrm{T}}$, H. denitrificans JCM $8864^{\mathrm{T}}$, $H$. mediterranei JCM $8866^{\mathrm{T}}, H$. volcanii JCM $8879^{\mathrm{T}}, H$. lucentense JCM $9276^{\mathrm{T}}, H$. alexandrinus JCM $10717^{\mathrm{T}}$ and $H$. sulfurifontis JCM $12327^{\mathrm{T}}$ were used as reference strains and cultivated in JCM 168 medium.

Cell lysis was observed by diluting cell suspensions with distilled water. Growth ranges and optimum $\mathrm{NaCl}$ and $\mathrm{Mg}^{2+}$ concentrations were determined using media containing $0-5.2 \mathrm{M} \mathrm{NaCl}$ and $0-1 \mathrm{M} \mathrm{MgCl}_{2} \cdot 6 \mathrm{H}_{2} \mathrm{O}$. For the determination of the optimum $\mathrm{pH}$ for growth, the following buffer systems (50 $\mathrm{mM}$ of each) were used: MES

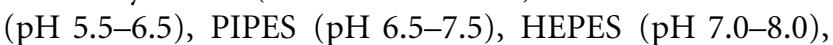
Tricine (pH 7.5-9.0) and CHES (pH 9.0-10.0). Magnesium salts were eliminated from media with a $\mathrm{pH}$ value exceeding 8.5. Growth temperature was determined in the range $4-60{ }^{\circ} \mathrm{C}$ by using a temperature gradient incubator. Growth rate was determined by measuring $\mathrm{OD}_{660}$ using a spectrophotometer. Anaerobic growth in the presence of arginine, DMSO and nitrate was tested in JCM 168 medium supplemented with $5 \mathrm{~g} \mathrm{l}^{-1}$ of each of the test compounds as described by Xin et al. (2000). Reduction of nitrate and formation of gas from nitrate were detected as described by Holding \& Collee (1971). To estimate the utilization of various carbohydrates and other compounds as carbon and energy sources, medium JCM 168 (without Casamino acids but with $0.1 \mathrm{~g}$ yeast extract $\mathrm{l}^{-1}$, $\mathrm{pH} 7.0$ with $50 \mathrm{mM}$ HEPES) was supplemented with $10 \mathrm{~g} \mathrm{l}^{-1}$ test compounds. Production of acids from carbohydrate was tested in the same medium but without the buffer and supplemented with $0.5 \mathrm{~g} \mathrm{l}^{-1}$ of the test compounds. The $\mathrm{pH}$ was determined at the end of growth. Thin layer chromatography of membrane lipids was conducted using the method described by Kamekura (1993). DNA G +C content was determined by the HPLC method of Tamaoka (1994). DNA-DNA hybridization was assessed by the fluorometric method (Ezaki et al., 1989). During these experiments, the DNA isolated from strain TL6 ${ }^{\mathrm{T}}$ was labelled. For $16 \mathrm{~S}$ rRNA gene sequence analysis, total DNA was extracted and purified using the method of Tamaoka (1994) adapted for halophilic archaea. The 16S rRNA genes were amplified by a PCR method with the following forward and reverse primers: 5'-TCCGGTTGATCCTGCCG (position 8-24 according to the Escherichia coli numbering system) and 5'-GGAGGTGATCCAGCCG (E. coli position 1540-1525). PCR products were sequenced using a BigDye Terminator Cycle sequencing kit (Pharmacia Biotech) and a DNA sequencer (ABI Prism; Applied Biosystems). The sequences obtained were aligned with other reported halobacterial $16 \mathrm{~S}$ rRNA gene sequences by using the CLUSTAL 1.7 program (Thompson et al., 1997). The phylogenetic tree was reconstructed by the neighbour-joining method (Saitou \& Nei, 1987) and was evaluated by bootstrap sampling. Tests for catalase and oxidase activities, formation of indole and starch hydrolysis were performed according to standard procedures (Holding \& Collee, 1971). The formation of sulfide was determined as described by Xin et al. (2000). The production of halocins was evaluated according to the procedure of Meseguer \& Rodriguez-Valera (1985). Hydrolysis of Tween 80 and gelatin was detected according to the method of Gutierrez \& Gonzalez (1972). Casein hydrolysis was tested on solidified JCM 168 medium (without Casamino acids but containing $1 \mathrm{~g}$ yeast extract $\mathrm{l}^{-1}$ ) supplemented with $1 \%$ skimmed milk. Sensitivity to antimicrobial agents was determined in growth medium containing $50 \mu \mathrm{g} \mathrm{ml}^{-1}$ of each of the following antimicrobial agents: novobiocin, bacitracin, anisomycin, aphidicolin, erythromycin, penicillin, ampicillin, rifampicin, chloramphenicol and neomycin. Tests were conducted in liquid culture and growth with or without antibiotics was compared.

Cells of strain $\mathrm{TL}^{\mathrm{T}}$ growing exponentially under optimal conditions were rod-shaped. Cells lysed in distilled water or culture medium without $\mathrm{NaCl}$. The novel strain stained Gram-negative. Colonies formed on agar plates were elevated, transparent and circular with whole margins. The colonies were beige-orange in colour. The range of $\mathrm{NaCl}$ concentration for growth was affected by the presence or absence of sodium glutamate and trisodium citrate in the JCM 168 culture medium. In the presence of these compounds, strain $\mathrm{TL}^{\mathrm{T}}$ was able to grow at $1.0-5.2 \mathrm{M} \mathrm{NaCl}$, but a higher concentration of $2.5 \mathrm{M} \mathrm{NaCl}$ was required for growth in the absence of these sodium salts. The optimum $\mathrm{NaCl}$ concentration for growth, $3.5 \mathrm{M}$, was not affected by the presence of additional sodium salts. The strain was able to grow at a concentration of $1 \mathrm{M} \mathrm{MgCl}_{2}$ or less, with an optimum of $0.4 \mathrm{M}$. Strain $\mathrm{TL}^{\mathrm{T}}$ grew between $\mathrm{pH} 6.0$ and $\mathrm{pH}$ 8.5, with an optimum of $\mathrm{pH}$ 7.0-7.5. Pigmentation of the strain was affected by temperature but not by the $\mathrm{NaCl}$ concentration. A high intensity of pigmentation was observed at high temperatures, up to $45^{\circ} \mathrm{C}$.

The novel strain was aerobic and unable to grow anaerobically even in the presence of DMSO, arginine or nitrate. Strain $\mathrm{TL}^{\mathrm{T}}$ formed sulfide from sulfur and sodium thiosulfate, formed indole from tryptophan and exhibited positive catalase and oxidase reactions. No hydrolysis of gelatin or casein was observed, but starch and Tween 80 were hydrolysed. The novel strain assimilated some carbohydrates and amino acids and formed acids from only a few carbohydrates as given in the species description. Strain $\mathrm{TL}^{\mathrm{T}}$ was sensitive to novobiocin, anisomycin, aphidicolin and rifampicin, but resistant to bacitracin, erythromycin, penicillin, ampicillin, chloramphenicol and neomycin. The differences between strain TL6 ${ }^{\mathrm{T}}$ and other members of the genus Haloferax are highlighted in Table 1.

TLC revealed that the strain possessed the glycerol diether analogues of phosphatidylglycerol (PG) and methyl ester of 
Table 1. Characteristics that distinguish strain $\operatorname{TL}^{\top}$ from other recognized species within the genus Haloferax

Strains: 1, strain TL6 $^{\mathrm{T}}$ (data from this study); 2, H. mediterranei JCM $8866^{\mathrm{T}}$ (Rodriguez-Valera et al., 1983); 3, H. lucentense JCM $9276^{\mathrm{T}}$ (Gutierrez et al., 2002); 4, H. gibbonsii JCM $8863^{\mathrm{T}}$ (Juez et al., 1986); 5, H. volcanii JCM $8879^{\mathrm{T}}$ (Mullakhanbhai \& Larsen, 1975; Torreblanca et al., 1986); 6, H. alexandrinus JCM $10717^{\mathrm{T}}$ (Asker \& Ohta, 2002); 7, H. denitrificans JCM 8864 ${ }^{\mathrm{T}}$ (Tomlinson et al., 1986); 8, H. sulfurifontis JCM $12327^{\mathrm{T}}$ (Elshahed et al., 2004). +, Positive; - , negative; ND, not determined.

\begin{tabular}{|c|c|c|c|c|c|c|c|c|}
\hline Characteristic & 1 & 2 & 3 & 4 & 5 & 6 & 7 & 8 \\
\hline \multicolumn{9}{|l|}{ Hydrolysis of: } \\
\hline Gelatin & - & + & - & + & - & + & + & + \\
\hline Casein & - & + & - & + & - & - & - & - \\
\hline Starch & + & + & - & - & - & - & - & - \\
\hline Tween 80 & + & + & + & + & - & + & - & + \\
\hline Nitrate reduction & - & + & - & + & + & + & + & + \\
\hline $\begin{array}{l}\text { Optimum } \mathrm{MgCl}_{2} \\
(\mathrm{mM})\end{array}$ & 400 & 20 & ND & 20 & 200 & $\mathrm{ND}$ & $\mathrm{ND}$ & 30 \\
\hline \multicolumn{9}{|l|}{ Sensitivity to: } \\
\hline Bacitracin & - & + & $\mathrm{ND}$ & - & $\mathrm{ND}$ & + & + & - \\
\hline Rifampicin & + & $\mathrm{ND}$ & $\mathrm{ND}$ & + & ND & - & + & - \\
\hline $\begin{array}{l}\text { DNA G }+ \text { C } \\
\text { content }(\mathrm{mol} \%)^{*}\end{array}$ & 63.7 & 60 & 64.5 & 61.8 & 63.4 & 59.5 & 65.3 & 60.5 \\
\hline \multicolumn{9}{|l|}{ Assimilation of: } \\
\hline Lactose & + & + & - & ND & ND & ND & $\mathrm{ND}$ & - \\
\hline L-Lysine & - & + & - & $\mathrm{ND}$ & ND & $\mathrm{ND}$ & $\mathrm{ND}$ & $\mathrm{ND}$ \\
\hline Maltose & + & + & - & + & ND & + & + & + \\
\hline Mannitol & - & + & - & $\mathrm{ND}$ & ND & ND & $\mathrm{ND}$ & - \\
\hline Mannose & - & $\mathrm{ND}$ & - & + & ND & $\mathrm{ND}$ & $\mathrm{ND}$ & $\mathrm{ND}$ \\
\hline L-Ornithine & + & $\mathrm{ND}$ & - & $\mathrm{ND}$ & ND & $\mathrm{ND}$ & $\mathrm{ND}$ & ND \\
\hline Starch & + & + & - & - & - & - & - & - \\
\hline \multicolumn{9}{|l|}{ Acid from: } \\
\hline Arabinose & - & $\mathrm{ND}$ & $\mathrm{ND}$ & + & ND & + & ND & + \\
\hline Glucose & - & + & $\mathrm{ND}$ & + & ND & + & + & + \\
\hline Maltose & - & + & $\mathrm{ND}$ & + & ND & + & + & + \\
\hline Sucrose & - & + & $\mathrm{ND}$ & + & ND & + & + & + \\
\hline $\begin{array}{l}\text { DNA-DNA } \\
\text { relatedness }(\%) \dagger\end{array}$ & 100 & 12 & 50 & 15 & 38 & 53 & 25 & 53 \\
\hline $\begin{array}{l}\text { 16S rRNA gene } \\
\text { similarity }(\%) \ddagger\end{array}$ & 100 & 98.2 & 99.3 & 98.8 & 99.3 & 99.3 & 98.7 & 97.3 \\
\hline
\end{tabular}

${ }^{*}$ Values obtained in this study.

$\dagger$ Hybridization values with biotin-labelled DNA from strain TL6 ${ }^{\mathrm{T}}$. $\ddagger$ Values are for gene sequence similarity to strain $\mathrm{TL}^{\mathrm{T}}$.

phosphatidylglycerol phosphate (PGP-Me) as phospholipids and glycolipid sulfated diglycosyl archaeol-1 (S-DGA1 ). The presence of S-DGA-1, the marker glycolipid of the genus Haloferax (Kamekura et al., 2004), supported the classification of the novel strain to this genus.

The 16S rRNA gene sequence of strain $\mathrm{TL}^{\mathrm{T}}$ showed a high degree of similarity (Table 1) to those of recognized species of the genus Haloferax. The reconstructed phylogenetic tree
(Fig. 1) supported the classification of the novel strain to the genus Haloferax.

The $\mathrm{G}+\mathrm{C}$ content of the total DNA for strain TL6 $^{\mathrm{T}}$ was $63.7 \mathrm{~mol} \%$. During the present investigation, the DNA $\mathrm{G}+\mathrm{C}$ contents of other strains belonging to the genus Haloferax were redetermined (see Table 1). DNA-DNA hybridization experiments (Table 1) showed that the relatedness between strain $\mathrm{TL}^{\mathrm{T}}$ and other species of the genus Haloferax ranged from 12 to $53 \%$ suggesting that this strain represents a novel species of the genus Haloferax.

The phenotypic data and phylogenetic data based on $16 \mathrm{~S}$ rRNA gene sequence comparisons clearly support the placement of strain TL $^{\mathrm{T}}$ as representing a novel species of the genus Haloferax, for which we propose the name Haloferax prahovense sp. nov.

\section{Description of Haloferax prahovense sp. nov.}

Haloferax prahovense (pra.ho.ven'se. N.L. neut. adj. prahovense pertaining to Prahova county, Romania, from where the type strain was isolated).

Cells are lysed in distilled water. Colonies are pigmented beige-orange and are circular, convex, translucent, entire and smooth. Growth occurs in the range of 2.5 to $5.2 \mathrm{M}$ $\mathrm{NaCl}$ with an optimum at $3.5 \mathrm{M}$. Growth occurs in a concentration of $1 \mathrm{M} \mathrm{Mg}^{2+}$ or less, with optimum growth at $0.4 \mathrm{M} \mathrm{Mg}^{2+}$. The $\mathrm{pH}$ range for growth is $6.0-8.5$, with an optimum at $\mathrm{pH} 7.0-7.5$. The temperature range for growth is $23-51{ }^{\circ} \mathrm{C}$, with an optimum at $38-48^{\circ} \mathrm{C}$. Chemoorganotrophic. Aerobic. Oxidase- and catalase-positive. Nitrate is not reduced to nitrite. Does not produce gas from nitrate. Indole is produced from tryptophan and $\mathrm{H}_{2} \mathrm{~S}$

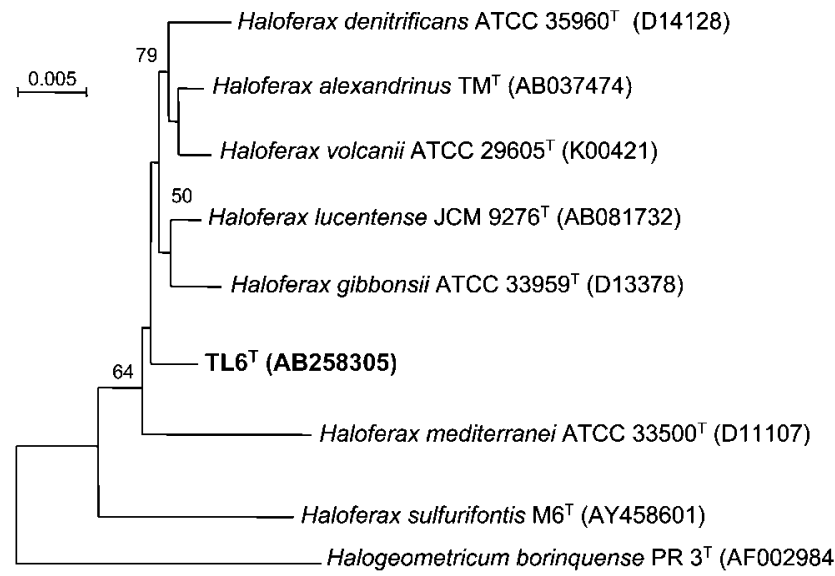

Fig. 1. Phylogenetic tree derived from the $16 \mathrm{~S}$ rRNA gene sequences showing the position of the strain $\mathrm{TL}^{\top}$ among species of the genus Haloferax. The tree was reconstructed by the neighbour-joining method. Bootstrap values $\geqslant 50 \%(100$ replicates) are shown. Bar, 0.005 substitutions per nucleotide position. 
is produced from sulfur and sodium thiosulfate. Starch and Tween 80 are hydrolysed, but gelatin and casein are not hydrolysed. Halocins are produced. The following substrates are used as carbon sources: glucose, arabinose, galactose, fructose, rhamnose, raffinose, D-xylose, maltose, sucrose, starch, lactose, glycerol, acetate, propionate, pyruvate, L-lactate, succinate, L-malate, fumarate, citrate, L-alanine, L-ornithine. Acid is produced from fructose and lactose. The following substrates are not used as carbon sources: mannose, D-ribose, mannitol, sorbitol, glycine, L-arginine, L-aspartate, L-glutamate and L-lysine. Sensitive to novobiocin, anisomycin, aphidicolin and rifampicin. Resistant to bacitracin, erythromycin, penicillin, ampicillin, chloramphenicol and neomycin. Lipids S-DGA-1, PGP-Me and PG are present, but phosphatidylglycerol sulfate is not present. The $\mathrm{G}+\mathrm{C}$ content of the total DNA of the type strain is $63.7 \mathrm{~mol} \%$

The type strain, TL6 ${ }^{\mathrm{T}}\left(=\mathrm{JCM} 13924^{\mathrm{T}}=\right.$ DSM $\left.18310^{\mathrm{T}}\right)$, was isolated from the saline Telega Lake, Prahova county, Romania.

\section{Acknowledgements}

A part of this study was supported by a postdoctoral fellowship grant from Japan Society for the Promotion of Science (JSPS) to M. E. during his stay at JCM.

\section{References}

Asker, D. \& Ohta, Y. (2002). Haloferax alexandrinus sp. nov., an extremely halophilic canthaxanthin-producing archaeon from a solar saltern in Alexandria (Egypt). Int J Syst Evol Microbiol 52, 729-738.

Castillo, A. M., Gutiérrez, M. C., Kamekura, M., Ma, Y., Cowan, D. A., Jones, B. E., Grant, W. D. \& Ventosa, A. (2006a). Halovivax asiaticus gen. nov., sp. nov., a novel extremely halophilic archaeon isolated from Inner Mongolia, China. Int J Syst Evol Microbiol 56, 765-770.

Castillo, A. M., Gutiérrez, M. C., Kamekura, M., Xue, Y., Ma, Y., Cowan, D. A., Jones, B. E., Grant, W. D. \& Ventosa, A. (2006b). Halostagnicola larsenii gen. nov., sp. nov., an extremely halophilic archaeon from a saline lake in Inner Mongolia, China. Int J Syst Evol Microbiol 56, 1519-1524.

Elshahed, M. S., Savage, K. N., Oren, A., Gutierrez, M. C., Ventosa, A. \& Krumholz, L. R. (2004). Haloferax sulfurifontis sp. nov., a halophilic archaeon isolated from a sulfide- and sulfur-rich spring. Int J Syst Evol Microbiol 54, 2275-2279.

Enache, M., Teodosiu, G., Faghi, A. M. \& Dumitru, L. (2000). Identification of halophilic Archaebacteria isolated from some Romanian salts lakes on the basis of lipids composition. Rev Roum Biol Ser Biol Vég 45, 93-99.

Ezaki, T., Hashimoto, H. \& Yabuuchi, E. (1989). Fluorometric deoxyribonucleic acid-deoxyribonucleic acid hybridization in microdilution wells as an alternative to membrane filter hybridization in which radioisotopes are used to determine genetic relatedness among bacterial strains. Int J Syst Bacteriol 39, 224-229.

Grant, W. D., Kamekura, M., McGenity, T. J. \& Ventosa, A. (2001). The order Halobacteriales. In Bergey's Manual of Systematic Bacteriology, 2nd edn, vol. 1, pp. 294-334. Edited by D. R. Boone \& R. W. Castenholz. New York: Springer.
Gutierrez, C. \& Gonzalez, C. (1972). Method for simultaneous detection of proteinase and esterase activities in extremely halophilic bacteria. Appl Microbiol 24, 516-517.

Gutierrez, M. C., Kamekura, M., Holmes, M. L., Dyall-Smith, M. L. \& Ventosa, A. (2002). Taxonomic characterization of Haloferax sp. (“H. alicantei") strain Aa 2.2: description of Haloferax lucentensis sp. nov. Extremophiles 6, 479-483.

Hezayen, F. F., Tindall, B. J., Steinbuchel, A. \& Rehm, B. H. A. (2002). Characterization of a novel halophilic archaeon, Halobiforma haloterrestris gen. nov., sp. nov., and transfer of Natronobacterium nitratireducens to Halobiforma nitratireducens comb. nov. Int J Syst Evol Microbiol 52, 2271-2280.

Holding, A. J. \& Collee, J. G. (1971). Routine Biochemical Tests. In Methods in Microbiology, vol. 6A, pp. 1-32. Edited by J. R. Norris \& D. W. Ribbons. London and New York: Academic Press.

Itoh, T., Yamaguchi, T., Zhou, P. \& Takashina, T. (2005). Natronolimnobius baerhuensis gen. nov., sp. nov., and Natronolimnobius innemongolicus sp. nov., novel haloalkaliphilic archaea isolated from soda lakes in Inner Mongolia, China. Extremophiles 9, 111-116.

Juez, G., Rodriguez-Valera, F., Ventosa, A. \& Kushner, D. J. (1986). Haloarcula hispanica spec. nov. and Haloferax gibbonsii spec. nov., two new species of extremely halophilic archaebacteria. Syst Appl Microbiol 8, 75-79.

Kamekura, M. (1993). Lipids of extreme halophiles. In The Biology of Halophilic Bacteria, pp. 135-161. Edited by R. H. Vreeland \& L. I. Hochstein. Boca Raton: CRC Press.

Kamekura, M., Mizuki, T., Usami, R., Youshida, Y., Horikoshi, K. \& Vreeland, R. H. (2004). The potential use of signature bases from $16 \mathrm{~S}$ rRNA gene sequences to aid the assignment of microbial strains to genera of halobacteria. In Halophilic Microorganisms, pp. 77-87. Edited by A. Ventosa. Berlin, Heidelberg: Springer.

Meseguer, I. \& Rodriguez-Valera, F. (1985). Production and purification of halocin H4. FEMS Microbiol Lett 28, 177-182.

Mullakhanbhai, M. F. \& Larsen, H. (1975). Halobacterium volcanii spec. nov., a Dead Sea halobacterium with a moderate salt requirement. Arch Microbiol 104, 207-214.

Oren, A., Elevi, R. V., Watanabe, S., Ihara, K. \& Corcelli, A. (2002). Halomicrobium mukohataei gen. nov., comb. nov., and emended description of Halomicrobium mukohataei. Int J Syst Evol Microbiol 52, 1831-1835.

Rodriguez-Valera, F., Juez, G. \& Kushner, D. J. (1983). Halobacterium mediterranei spec. nov., a new carbohydrate-utilizing extreme halophile. Syst Appl Microbiol 4, 369-381.

Saitou, N. \& Nei, M. (1987). The neighbor-joining method: a new method for reconstructing phylogenetic trees. Mol Biol Evol 4, 406-425.

Tamaoka, J. (1994). Determination of DNA base composition. In Chemical Methods in Prokaryotic Systematics, pp. 463-470. Edited by M. Goodfellow \& A. G. O'Donnell. Chichester: Wiley.

Thompson, J. D., Gibson, T. J., Plewniak, F., Jeanmougin, F. \& Higgins, D. G. (1997). The CLUSTAL_X interface: flexible strategies for multiple sequence alignment aided by quality analysis tools. Nucleic Acids Res 25, 4876-4882.

Tindall, B. J., Tomlinson, G. A. \& Hochstein, L. I. (1989). Transfer of Halobacterium denitrificans (Tomlinson, Jahnke, and Hochstein) to the genus Haloferax as Haloferax denitrificans comb. nov. Int J Syst Bacteriol 39, 359-360.

Tomlinson, G. A., Jahnke, L. L. \& Hochstein, L. I. (1986). Halobacterium denitrificans sp. nov., an extremely halophilic denitrifying bacterium. Int J Syst Bacteriol 36, 66-70.

Torreblanca, M., Rodriguez-Valera, F., Juez, G., Ventosa, A., Kamekura, M. \& Kattes, M. (1986). Classification of non-alkaliphilic 
halobacteria based on numerical taxonomy and polar lipid composition, and description of Haloarcula gen. nov. and Haloferax gen. nov. Syst Appl Microbiol 8, 89-99.

Ventosa, A. (2001). Genus V. Haloferax. In Bergey's Manual of Systematic Bacteriology, 2nd edn, vol. 1, pp. 315-318. Edited by D. R. Boone, R. W. Castenholz \& G. M. Garrity. New York, Berlin, Heidelberg: Springer.

Vreeland, R. H., Straight, S., Krammes, J., Dougherty, K., Rosenzweig, W. D. \& Kamekura, M. (2002). Halosimplex carlsbadense gen. nov., sp. nov., a unique halophilic archaeon, with three $16 \mathrm{~S}$ rRNA genes, that grows only in defined medium with glycerol and acetate or pyruvate. Extremophiles 6, 445-452.
Wainø, M., Tindall, B. J. \& Ingvorsen, K. (2000). Halorhabdus utahensis gen. nov., sp. nov., an aerobic, extremely halophilic member of the Archaea from Great Salt Lake, Utah. Int J Syst Evol Microbiol 50, 183-190.

Xin, H., Itoh, T., Zhou, P., Suzuki, K., Kamekura, M. \& Nakase, T. (2000). Natrinema versiforme sp. nov., an extremely halophilic archaeon from Aibi salt lake, Xinjiang, China. Int J Syst Evol Microbiol 50, 1297-1303.

Xue, Y., Fan, H., Ventosa, A., Grant, W. D., Jones, B. E., Cowan, D. A. \& Ma, Y. (2005). Halalkalicoccus tibetensis gen. nov., sp. nov., representing a novel genus of haloalkaliphilic archaea. Int J Syst Evol Microbiol 55, 2501-2505. 